\begin{tabular}{|l|l|l|}
\hline \multicolumn{2}{|c|}{ PublisherInfo } \\
\hline \hline PublisherName & $:$ & BioMed Central \\
\hline \hline PublisherLocation & $:$ & London \\
\hline \hline PublisherImprintName & $:$ & BioMed Central \\
\hline \hline
\end{tabular}

\title{
Rat olfaction molded early
}

\begin{tabular}{|l|l|l||}
\hline \multicolumn{2}{|c|}{ ArticleInfo } \\
\hline \hline ArticleID & $:$ & 5025 \\
\hline \hline ArticleDOI & $:$ & $10.1186 /$ gb-spotlight-20050708-01 \\
\hline \hline ArticleCitationID & $:$ & spotlight-20050708-01 \\
\hline \hline ArticleSequenceNumber & $:$ & 88 \\
\hline \hline ArticleCategory & $:$ & Research news \\
\hline ArticleFirstPage & $:$ & 1 \\
\hline \hline ArticleLastPage & $:$ & 3 \\
\hline \hline & & RegistrationDate : 2005-7-8 \\
\hline ArticleHistory & $:$ & OnlineDate \\
\hline \hline ArticleCopyright & $:$ & BioMed Central Ltd2005-7-8 \\
\hline \hline ArticleGrants & $:$ & \\
\hline \hline ArticleContext & $:$ & 130595511 \\
\hline \hline
\end{tabular}


The odors that newborn rats are exposed to appear to govern the development of synapses that carry information into the rat olfactory cortex, the seat of odor perception, researchers report in Neuron this week.

Kevin Franks and Jeffry Isaacson of the University of California, San Diego, found that in newborn rats, early olfactory experiences caused changes in the relative amounts of two types of glutamate receptors in lateral olfactory tract fibers. Specifically, they observed a decrease in the number of NMDA receptors, which are believed to be important in synaptic plasticity and long-term changes, relative to AMPA receptors, which mediate fast synaptic transmission. The researchers suggest this phenomenon might be associated with "olfactory imprinting," the strong attachment to maternal odors that occurs early in mammalian development.

"The ability of the animal to smell caused downregulation in the number of NMDA receptors," Isaacson told The Scientist. "Very early in rat development, there is quite robust NMDA receptormediated, long-term potentiation from the sensory synapses into the cortex, but later in life, after the animal has had time to smell, the loss of NMDA receptors makes it difficult to induce any long-term changes in the strength of the synaptic transmission."

To study the synaptic modifications that occur during development, the authors took advantage of the layered architecture of the rat's olfactory cortex. "The stratification makes this a nice experimental model to use," said Kurt Illig of the University of Virginia, who did not participate in the research. "The authors were able to selectively stimulate different types of cells and look at the development of the responses for each of those layers independently in an in vitro preparation. The loss of NMDA receptors they observed could be a mechanism by which early olfactory experience shapes the cortex to respond to particular odors."

To test for the role of sensory experience in the synaptic changes, the authors occluded one of the nostrils in newborn rats, depriving one side of the brain of olfactory stimulation, and compared the two sides of the brain in each animal. "This is a great technique because the olfactory information in the brain is ipsilateral," said Isaacson.

The results pointed to the existence of a critical period during which sensory synapses are especially plastic, a phenomenon that also has been shown in the visual, auditory, and somatosensory systems. "Olfactory deprivation caused loss of NMDA receptors in young rats, but not in rats 2 months old or so," he said.

"There have been very few researchers who have looked at how experience can modify the olfactory cortex," said Ben Philpot of the University of North Carolina at Chapel Hill, who wrote a related preview. "This work shows that you can have changes with olfactory experience in the cortex very early on."

Philpot added that the changes in the receptor levels may also be involved in the pruning back of exuberant projections from the olfactory bulb to the olfactory cortex. "This would be a nonexclusive possibility, equally exciting," he said. 
According to Takao Hensch of the Riken Brain Science Institute in Saitama, Japan, who was not part of the research team, the results bode well for identifying a critical period in the olfactory system. "What Isaacson et al. will need to show in the future is that the NMDA-mediated events at lateral olfactory tract synapses indeed have behavioral consequences. Does nostril occlusion delay the critical period for imprinting, as they would suggest?"

\section{References}

1. C. Delude, "On the trail of an odor map," The Scientist, 8(20):22, October 25, 2004., [http://www.the-scientist.com/2004/10/25/22/1]

2. K.M. Franks, J.S. Isaacson, "Synapse-specific downregulation of NMDA receptors by early experience: a critical period for plasticity of sensory input to olfactory cortex," Neuron, 47:1-14, July 7, 2005., [http://www.neuron.org]

3. Jeffry S. Isaacson, [http://neuro.ucsd.edu/summaries/jisaacson.asp]

4. K. Heyman, "Neurophysiology: dust clearing on the long-term potentiation debate," The Scientist, 19(10):14, May 23, 2005., [http://www.the-scientist.com/2005/5/23/14/1]

5. Kurt R. Illig, [http://www.faculty.virginia.edu/krillig]

6. Ben Philpot, [http://www.med.unc.edu/physiolo/fac_philpot.htm]

7. B.D. Philpot, "Sniffing out NMDA receptors in the olfactory cortex," Neuron, 47:3-5, July 7, 2005. [http://www.neuron.org]

8. Takao Hensch, [http://www.brain.riken.go.jp/english/b_rear/b4_lob/t_hensch.html] 